\title{
The Development of Blended Leaning Model by Using Active Learning Activity to Develop Learning Skills in 21 st Century
}

\author{
Nuanphan Chaiyama
}

\begin{abstract}
This research is the development of a learning model that focuses on learners by allowing students to be practiced through thinking, analyzing, reason in solving problems and sharing knowledge themselves, Focus on professional learning activities, by using an integrated information technology network for learning management using learning processes, procedures, connectivity and continuously both in classroom and online learning to develop $\mathbf{2 1}^{\text {st }}$ century learning skills of learners. Those are higher order learning skills, information and digital literacy skills. The result of quality evaluation of learning model was at a very good level $(\bar{X}=4.51)(S D=0.12)$. Students had post-test learning skills scores higher than pre-test at .01 level of significant. It shows that the learning model developed by researcher can develop learning skills in 21 st century of learner's effectiveness.
\end{abstract}

Index Terms-Blended learning, active leaning activity, learning skills in 21 st century.

\section{INTRODUCTION}

In the 21st century, the global society has changed rapidly in all aspects. New-age people need to have effective learning methods and lifelong learning, in order to be able to solve problems in new situations. The process of developing knowledge and skills is very important and necessary for the development of human potential. Therefore, the approach to modern education management needs to change the teaching method to enhance the students to have the skills necessary to live in the 21st century:- They are 1) Critical Thinking and Problem Solving 2) Creativity and Innovation 3) Cross-cultural Understanding 4) Collaboration, Teamwork and Leadership 5) Communications, Information, and Media Literacy 6) Computing and ICT Literacy 7) Career and Learning self-reliance [1]. In addition, teachers have to develop teaching styles and develop the necessary skills to live through profound learning. Practicing perception skills, giving valuable meaning and life goals through connecting and systematic thinking. Questioning that causes thoughtful thinking, seeking knowledge, self-awareness and awareness of the world, problem solving and develops ideas set that consistent with the situation and lead to creativity [2], [3] can be applied and solved in daily life. Which will be a continuous process for creating a complete human being both of knowledge and aptitude ability to think and practice. Awareness of their own and environment, expression social

Manuscript received April 3, 2019; revised August 24, 2019

Nuanphan Chaiyama is with Institute of Physical Education Udon-Thani, Thailand (e-mail: dr.neeon@gmail.com). roles both in work and in the community [4].

The 21st century learning approach found that blended learning, which is a teaching system that blended between classroom (F2F) and online learning via a computer network [5]-[8] has been very popular in higher education institutions around the world. Since it is a flexible learning management that brings the strengths of various teaching sciences to fill each weakness of learning, making it possible to solve problems of learning management appropriately. By focusing on the active learning participation of learners by allowing students doing through practice in seeking knowledge and learning interactively [9], including connecting to social network until can be applied, analyze, synthesize, evaluate or create new things by the instructor acting in giving advice, encourage to learn and create knowledge by themselves which will be meaningful learning and lead to self-development to their full potential.

\section{RESEARCH OBJECTIVES}

1) To develop blended leaning model by using active learning activity to develop learning skills in the $21^{\text {st }}$ century for higher students.

2) To study efficacy of blended learning model by using active learning activity to develop learning skills in the $21^{\text {st }}$ century for higher students.

\section{ReSEARCH MethODOLOGY}

There are three phases of this study:

\section{A. Development of Learning Model}

This step is studying about the basic information, principles, concepts, theories and related research for synthesis of complements and create a leaning model. Development of learning processes and activities [10] including the creation of research tool and assessment forms for learning activities.

1) Experimental tool are:

a) Lesson plan by combining between classroom (F2F) and online learning (e-Learning), focusing on organizing active learning activities that promote learning skills in the 21st century, with 8 lesson plans and investigate the appropriateness them by 5 experts.

b) Online lesson website on learning management system (LMS, which can be accessed at: http://eeducation.nana-ideas.com/ for presenting the main information, students can register for learning 
course, communicate between learners and teachers. Do activities according to the learning management plan; deliver learning activities in each step. As well as opening another communication channel through the Facebook group.

2) Collecting data tool are:

a) Learning outcome assessment form to be used to evaluate the work pieces that the learners have prepared in each step of learning management, including presentations that are stored in the learning management system by rubric score assessment.

b) Learning record and assessment form after the activity to reflect learning, self-assessment, and express opinions about learning activities, which is divided into issues related to learners, instructors and media, also the appropriateness of activities and the duration of learning activities, summary and evaluation of learning.

c) Learning skills in the $21 \mathrm{st}$ century assessment form, which are competency assessment of higher order thinking skills, information literacy skills and digital literacy skills, was assessed during learning management by using rubric score assessment.

All assessment tools were evaluated validity by 5 experts in order to analyze the index of consistency (IOC) by selecting questions that have validity between $0.05-1.00$ which is considered the questions that can be used.

d) The 21st Century learning skills test to assess learning skills before and after learning according to the developed learning model:-

- Higher order thinking skills test was developed by N.Chaiyama [11] according to L.W. Anderson \& D.R. Krathwohl concept [12] is a multiple-choice question of 60 items, with the Conbach's alpha score 0.81 .

- Information literacy skills test, the researcher has improved from K.Sriphan's information literacy test. [13]. It is a multiple-choice question with 50 items, with the Conbach's alpha score of 0.89 .

- Digital literacy skill test, was developed by W. Techataweewan \& U. Prasertsin [14] consisting of 54 questions with the Conbach's alpha score 0.91.

\section{B. Efficiency Investigation of Learning Model}

The researcher used the prototype of the learning model to synthesize up to investigate quality by 5 experts using a questionnaire. Use the criteria for investigation the quality of the learning model created in each area must have a value that is not lower than the good level, with an average score from 3.50 up. And bring suggestions from experts to improve the learning model to be more quality. Then using the developed learning model to pilot experiment with 24 undergraduate students, which is non-sample groups of Faculty of Education in first semester, academic year 2018 in courses ED032005, Information Technology for Teachers, in order to study the feasibility of practice and the learning process, according to the learning model.

\section{Quasi-Experimental Research to Find the Effectiveness of Learning Model.}

1) Population and sample group a) The population used for research is undergraduate students in the Institute of Physical Education, academic year 2018 .

b) The sample group is undergraduate students of Institute of Physical Education, Udon-Thani, enrolled in the course ED031007 Information and Communication Technology for Teachers, studying in the second semester, academic year 2018 with 30 students in 1 room by selecting purposive sampling.

2) Research tool, used the developed tool and improved the quality from the phase 1 of the experiment.

3) The research plan to be a quasi-experimental research. One group pretest-posttest design was conducted as the following steps.

a) Preparation before teaching by orientation about learning methods, students grouping, register and practice using the learning management system. And then allow students to do measurement of learning skills in the 21 st century before study.

b) Conduct teaching according to the developed learning management model, which is a combination of classroom (F2F) and online learning using active learning activities for students as the planned, collect data and evaluate during learning management.

c) Measurement of learning skills in the $21^{\text {st }}$ century after completing the experiment, according to the learning plan. The researcher measures the learning skills of the 21 st century after studying.

4) Data collection from learning management with various tool, includes various events that occurred during teaching and learning by recording and assessment forms after the activity discussion and commenting with group members, work pieces stored in the learning management system (LMS) and presentation of learning outcome in the classroom.

5) Data analysis, the researcher has used the data obtained from the collection to analyze as follows.

a) Learning outcome, of the work pieces, as average and standard deviation, and translate the mean value into learning level.

b) Learning skills in $21 \mathrm{st}$ Century assessment as higher order thinking skills, information literacy skills and digital literacy skills by finding the mean and standard deviation and translating the mean to each skill level and compare with the criteria and interpret the meaning as the setting and concluded that the students have the level of learning skill for each level.

c) Score of the higher order thinking skills test, information literacy skill test, and digital literacy skills test before and after study, analyzed by finding the mean and standard deviation, comparing the average score before and after learning by using t-test in a single sample group.

6) Conclusion of learning outcomes base on the developed learning model.

Evaluation of effectiveness of a blended learning model by using active learning activities to develop learning skills in $21^{\text {st }}$ century for higher students can make the learners with the characteristics as follows: - students have an average score from the higher order thinking skills test, the 
Information literacy skills test, and the digital literacy skills test after study higher than before study at .01 level of significant.

\section{RESEARCH RESULTS}

\section{A. Result of Development Learning Model}

The blended learning model by using active learning activity to develop learning skills in $21^{\text {st }}$ century (see Fig. 1) developed by the researcher, consisted of 4 complements (See Table I).

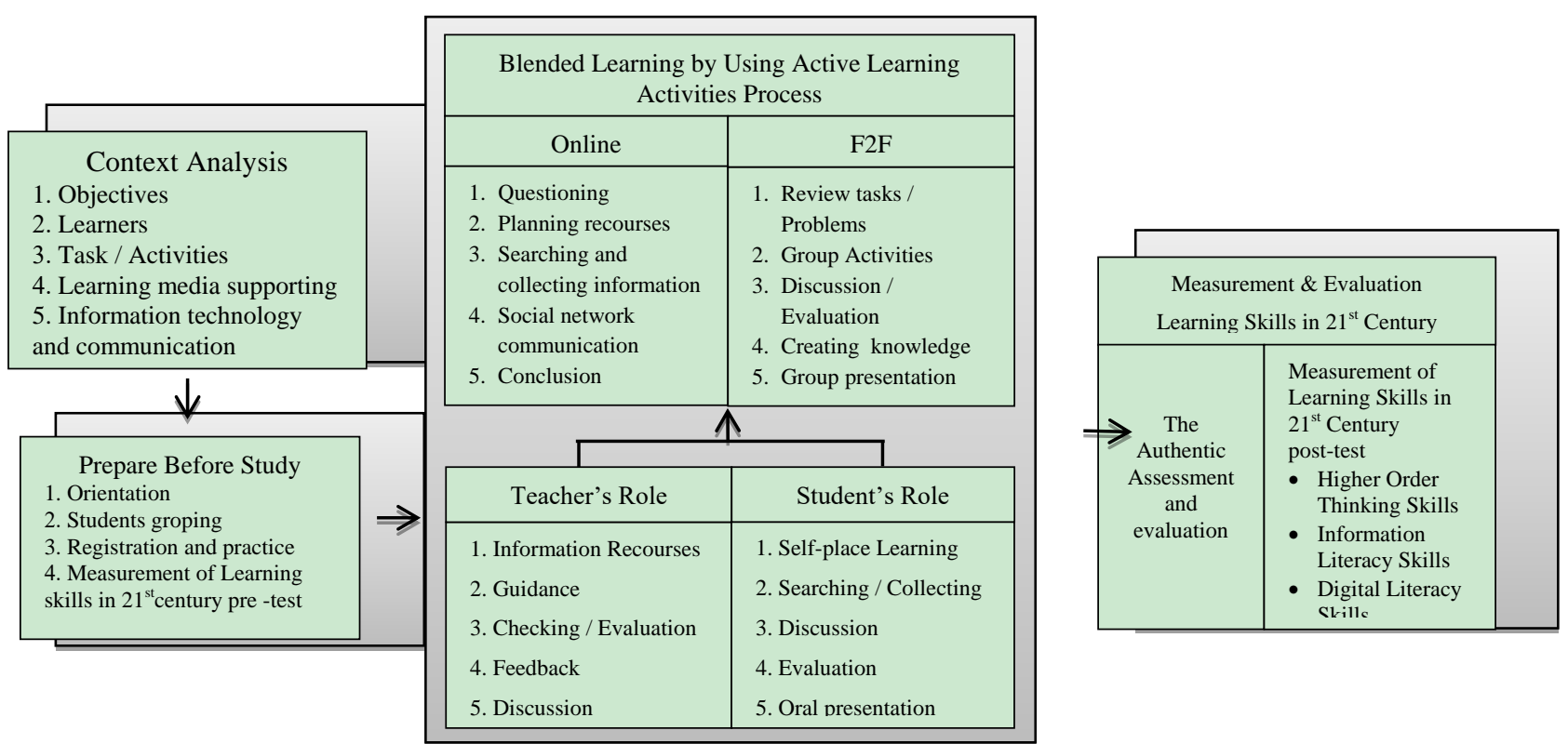

Fig. 1. The blended leaning model by using active learning activity to develop learning skills in 21 st century.

TABLE I: COMPLEMENTS OF THE BLENDED LEARNING MODEL BY USING ACTIVE LEARNING ACTIVITY TO DEVELOP LEARNING SKILLS IN 21 TH CENTURY

\begin{tabular}{|c|c|c|c|}
\hline Principle of Leaning Model & Context Analysis & Learning Management Process & Measurement and Evaluation \\
\hline 1. AAA Model & 1. Objectives & 1.Prepare Before Study & 1. The authentic assessment and \\
\hline 2. Blended learning & 2. Learners & 1) Orientation & Evaluation \\
\hline 3. Active learning & 3. Task / Activities & 2) Students groping & 2. Measurement of learning skills in \\
\hline 4. Students in higher education & 4. Learning media & 3) Registration and practice & $21^{\text {st }}$ century post-test \\
\hline 5. Learning Skills in $21^{\text {st }}$ Century & 5. Information Technology & 4) Measurement of Learning skills in & 1) Higher Order Thinking Skills \\
\hline 6. Teacher's role & and communication & $\begin{array}{l}21^{\text {st }} \text { century pre -test } \\
\text { Rlended }\end{array}$ & 2) Information Literacy Skills \\
\hline 7. Student's role & & $\begin{array}{l}\text { 2. Blended Learnıng by Using Active } \\
\text { Learning Activity }\end{array}$ & 3) Digital Literacy Skills \\
\hline & & 1) Classroom (F2F) & \\
\hline & & 2) Online & \\
\hline
\end{tabular}

\section{B. Result of Investigation Learning Model}

The efficiency of the learning model developed by the researcher was at a very good level $(\overline{\mathrm{X}}=4.51)(S D=0.12)$ and can be used learning management to achieve the objectives of the learning model. (see Table II)

From the introduction of the developed learning model to pilot experiment with 24 undergraduate students, non-sample groups of faculty of education in first semester, academic year 2018 in courses ED032005 Information Technology for Teachers by 5 activities. The results of the development of learning skills in the $21^{\text {st }}$ century found that, in general most students understand the learning process as well as learning model and satisfied with the teaching and learning process, as well as sharing activities with classmates. Using media, equipment and learning resources that support learning management both in classroom and online learning. In addition, most students are able to show their role appropriately, allowing them to continue to learn, according to the learning model that has been developed continuously.

\section{Results of Used Learning Model}

The researcher used the learning model obtained from the research in phase 1 to experiment with learning management in order to study the effectiveness of the model on the development of learning skills of the 21 st century. Including, studying the opinions of learners towards the learning model developed by the researcher. The sample group of 30 students is undergraduate students, Faculty of Education, Institute of Physical Education Udon-Thani registered in the course ED031007 Information and Communication Technology for Teachers, second semester of the academic year 2018, spent 8 weeks in the experiment, of completing the teaching program. The researcher evaluated learning outcome of learning skills level competency and learning skills in the 21 st century by using the test of higher order thinking skills, information literacy skill and digital literacy skill after study which is the same version that the students have done before teaching and learning. The results of analysis of the following data:-

1) Higher order thinking skills, students have the higher order thinking skills competency after learning, according to the overall was at a good level. And when considered in each skill was found that learners with the highest level of thinking skills in attributing and checking 
skills (see Table III) and from post-test scores, found that learners had higher level of higher order thinking skills after learning, developed in all skills at .01 level of significant. (see Table IV)

2) Information literacy skills, students have the competency of information literacy after learning according to the overall was at a good level. When considered each skill, it was found that the learners had the most information literacy skills in terms of access to information that was needed effectively and efficiently (see Table V) and from checking scores after learning. It was found that learners had a higher level of information literacy skills after studying 5 standards at .01 level of significant. (see Table VI).

3) Digital literacy skills, students have the digital literacy skills competency after learning, according to the overall was at a good level. And when considering each skill, it was found that students had the most digital literacy skills in collaboration skills (see Table VII) and from checking scores after learning, it was found that learners had a digital literacy skills score after studying higher than the scores before studying all skills at .01 level of significant. (see Table VIII).

Based on the evaluation of the competency and learning skills in 21 st century scores after the study, shows that learning through learning management model developed by the researcher can help develop learning skills in 21 st century to be effective for learners.

TABLE II: THE EFFICIENCY OF BLENDED LEARNING MODEL BY USED ACTIVE LEARNING ACTIVITY WAS INVESTIGATED BY EXPERTS

\begin{tabular}{|c|c|c|c|}
\hline \multirow{2}{*}{ Data Evaluation } & \multicolumn{3}{|c|}{ Results of efficiency } \\
\hline & $\bar{X}$ & S.D. & Efficiency Level \\
\hline $\begin{array}{l}\text { 1. The Principles and concepts of } \\
\text { Learning Model }\end{array}$ & 4.60 & .548 & Very Good \\
\hline $\begin{array}{l}\text { 2. The objective of Learning } \\
\text { Model }\end{array}$ & 4.60 & .548 & Very Good \\
\hline 3. Context Analysis & 4.60 & .548 & Very Good \\
\hline 4. Preparation before study & 4.60 & .548 & Very Good \\
\hline $\begin{array}{l}\text { 5. Blended learning by using } \\
\text { active learning activities process }\end{array}$ & 4.60 & .548 & Very Good \\
\hline 1) Online Learning & 4.60 & .548 & Very Good \\
\hline - Questioning & 4.40 & .548 & Good \\
\hline - Planning recourses & 4.40 & .548 & Good \\
\hline $\begin{array}{l}\text { - Searching and collecting } \\
\text { information }\end{array}$ & 4.60 & .548 & Very Good \\
\hline $\begin{array}{l}\text { - Social network } \\
\text { communication }\end{array}$ & 4.60 & .548 & Very Good \\
\hline - Conclusion & 4.20 & .447 & Good \\
\hline 2) Classroom Learning (F2F) & 4.60 & .548 & Very Good \\
\hline - Review tasks / Problems & 4.40 & .548 & Good \\
\hline - Group Activities & 4.60 & .548 & Very Good \\
\hline - Discussion / Evaluation & 4.40 & .548 & Good \\
\hline - Creating knowledge & 4.40 & .548 & Good \\
\hline - Group presentation & 4.60 & .548 & Very Good \\
\hline 6. Measurement and Evaluation & 4.40 & .548 & Good \\
\hline $\begin{array}{l}\text { 7. The possibility to utilize } \\
\text { blended learning model by used } \\
\text { active leaning activity to use in }\end{array}$ & 4.60 & .548 & Very Good \\
\hline
\end{tabular}

\begin{tabular}{rlll}
\hline \hline learning management & & & \\
\hline Average & 4.51 & .120 & Very Good \\
\hline \hline
\end{tabular}

TABLE III: STUDENT'S COMPETENCY IN EACH SKILL OF HIGHER ORDER THINKING SKILLS AFTER STUDY

\begin{tabular}{llll}
\hline $\begin{array}{c}\text { Higher Order } \\
\text { Thinking Skills }\end{array}$ & $\overline{\mathrm{X}}$ & SD. & Competency Level \\
\hline Executing & 3.05 & .62 & Good \\
\hline Implementing & 2.63 & .50 & Good \\
\hline Differentiating & 3.05 & .62 & Good \\
\hline Organizing & 2.95 & .52 & Good \\
\hline Attributing & 3.68 & .48 & Very Good \\
\hline Checking & 3.58 & .51 & Very Good \\
\hline Critiquing & 3.21 & .42 & Good \\
\hline Generating & 2.89 & .46 & Good \\
\hline Planning & 2.95 & .23 & Good \\
\hline Producing & 2.63 & .50 & Good \\
\hline Average & 3.06 & .59 & Good \\
\hline \hline
\end{tabular}

\section{DISCUSSION}

The blended learning model by using active learning activity to develop learning skills in 21 st century was developed by research. Experts have opinions that they are appropriate to use learning management at a very good level. The development of the learning model consists of the systematic learning development principles, the result of learning management process is respectively and appropriate to develop learning skills in the 21 st century by organizing active learning activities through classroom and online learning that promotes learning and creative knowledge themselves also benefits the learners in increasing learning efficiency in conformity with the research done by $\mathrm{F}$. Mossavar-Rahmani, and C. Larson-Daugherty [15]. The score of students studied through learning model was developed by the researcher have an average score of learning skills in 21 st century from the higher order thinking skills, Information skills, and digital literacy skills after study higher than before study were at .01 level of significance and had competency in each skill at good level which is in accordance with the research hypothesis of this research.

Learning management according to the learning model developed by the researcher, students have opinions that learning in this way has more time to learn and can learn at any time through various media and learning resources on the Internet. Students are able to communicate, dare to talk and ask questions with more instructors, learned new techniques and methods of learning. From using Internet technology in study, research, communication, online interaction and presentation of information can develop digital literacy skills from using information technology for learning well, in conformity with the concept of L.Jeffrey, B. Hegarty, O. Kelly,M . Penman, D. Coburn, and J. McDonald. [16] according to the developed model is appropriate and helps promote and develop learning skills of the 21 st century, as 
well, having fun and enjoy during learning activities, having the opportunity to practice more systematic thinking skills Learning and able to create knowledge by themselves from participating in learning activities, exchange opinions and compare their opinions with friends within the group and classmates on various knowledge issues. Making it possible to develop skills in working as a group and having better human relations with classmates. Have confidence in discussions and presentations, and propose guidelines for applying knowledge in other situations and also need to have more teaching in this type in other courses.

TABLE IV: STUdENT's AVERAGE SCORE OF HIGHER ORDER THINKING SKILLS BEFORE AND AFTER STUDY THORUGH LEARNING MODEL

\begin{tabular}{|c|c|c|c|c|c|c|c|}
\hline \multicolumn{8}{|c|}{$N=30$} \\
\hline \multirow{2}{*}{$\begin{array}{l}\text { Higher Order } \\
\text { Thinking Skills }\end{array}$} & \multirow{2}{*}{ Items } & \multicolumn{2}{|c|}{ Pre-Test } & \multicolumn{2}{|c|}{ Post-Test } & \multirow{2}{*}{$\mathrm{t}$} & \multirow{2}{*}{$\mathrm{P}^{*}$} \\
\hline & & $\overline{\mathrm{X}}_{1}$ & $\mathrm{SD}_{.1}$ & $\overline{\mathrm{X}}_{2}$ & $\mathrm{SD}_{2}$ & & \\
\hline Executing & 6 & 3.63 & .999 & 4.97 & .890 & -15.232 & .000 \\
\hline Implementing & 5 & 2.83 & .531 & 4.30 & .750 & -15.832 & .000 \\
\hline Differentiating & 6 & 3.57 & .679 & 5.20 & .664 & -14.548 & .000 \\
\hline Organizing & 5 & 3.30 & .466 & 4.43 & .504 & -17.954 & .000 \\
\hline Attributing & 9 & 5.23 & .971 & 6.90 & .712 & -13.813 & .000 \\
\hline Checking & 5 & 3.00 & .643 & 4.33 & .711 & -13.359 & .000 \\
\hline Critiquing & 6 & 3.27 & .583 & 5.03 & .669 & -14.253 & .000 \\
\hline Generating & 6 & 3.23 & .858 & 5.03 & .669 & -13.801 & .000 \\
\hline Planning & 6 & 3.17 & .648 & 4.70 & .794 & -14.699 & .000 \\
\hline Producing & 6 & 3.07 & .450 & 4.67 & .711 & -14.102 & .000 \\
\hline Average score & 60 & 34.30 & 2.818 & 49.57 & 3.785 & -38.920 & .000 \\
\hline
\end{tabular}

TABLE V: STUDENT’S COMPETENCY IN EACH SKILL OF INFORMATION LITERACY SKILLS AFTER STUDY

\begin{tabular}{|c|c|c|c|}
\hline Information Literacy Skills & $\overline{\overline{\mathrm{X}}}$ & S.D. & Competency Level \\
\hline The Information literate student determines the nature and extent of the information needed. & 3.26 & 0.45 & Good \\
\hline The information literate accesses needed information effectively and efficiently. & 3.74 & 0.45 & Very Good \\
\hline $\begin{array}{l}\text { The information literate student evaluates information and its sources critically and incorporates } \\
\text { selected information into his or her knowledge base and value system. }\end{array}$ & 3.26 & 0.45 & Good \\
\hline $\begin{array}{l}\text { The information literate student, individually or as a member of a group, uses information } \\
\text { effectively to accomplish a specific purpose. }\end{array}$ & 3.16 & 0.37 & Good \\
\hline $\begin{array}{l}\text { The information literate student understands of the economic, legal, and social issues surrounding } \\
\text { the use of information and accesses and uses information ethically and legally. }\end{array}$ & 3.11 & 0.32 & Good \\
\hline Average & 3.30 & 0.60 & Good \\
\hline
\end{tabular}

TABLE VI: STUDENT’S AVERAGE SCORE OF INFORMATION LITERACY SKILLS BEFORE AND AFTER STUDY THROUGH LEARNING MODEL

$$
N=30
$$

Information Literacy Skills

$$
\text { Pre-Test Post-Test }
$$

\begin{tabular}{|c|c|c|c|c|c|c|c|}
\hline $\begin{array}{l}\text { The Information literate student determines the nature and extent of the } \\
\text { information needed. }\end{array}$ & 9 & 5.83 & 1.392 & 7.47 & 1.408 & -9.642 & .000 \\
\hline $\begin{array}{l}\text { The information literate accesses needed information effectively and } \\
\text { efficiently. }\end{array}$ & 11 & 6.70 & 1.317 & 8.77 & 1.654 & -7.511 & .000 \\
\hline $\begin{array}{l}\text { The information literate student evaluates information and its sources critically } \\
\text { and incorporates selected information into his or her knowledge base and value } \\
\text { system. }\end{array}$ & 12 & 6.47 & 1.008 & 8.23 & 1.104 & -9.021 & .000 \\
\hline $\begin{array}{l}\text { The information literate student, individually or as a member of a group, uses } \\
\text { information effectively to accomplish a specific purpose. }\end{array}$ & 10 & 4.93 & .868 & 6.70 & .988 & -11.273 & .000 \\
\hline $\begin{array}{l}\text { The information literate student understands of the economic, legal, and social } \\
\text { issues surrounding the use of information and accesses and uses information } \\
\text { ethically and legally. }\end{array}$ & 8 & 5.23 & .858 & 6.67 & .844 & -12.540 & .000 \\
\hline Average score & 50 & 29.17 & 2.561 & 37.83 & 3.415 & -17.367 & .000 \\
\hline
\end{tabular}

$\begin{array}{lllll}\text { Items } & \overline{\mathrm{X}}_{1} & \mathrm{SD}_{\cdot 1} & \overline{\mathrm{X}}_{2} & \mathrm{SD}_{\cdot 2}\end{array}$ 
TABLE VII: STUDENT’S COMPETENCY IN EACH SKILL OF DIGITAL LITERACY SKILLS AFTER STUDY

\begin{tabular}{|c|c|c|c|c|}
\hline Digital Literacy Skills & Index & $\bar{X}$ & S.D. & Competency Level \\
\hline \multirow{3}{*}{ Operation Skills } & Cognition & 3.17 & .699 & Good \\
\hline & Innovation & 3.23 & .679 & Good \\
\hline & Presentation & 3.57 & .504 & Very Good \\
\hline \multirow{3}{*}{ Thinking Skills } & Analysis & 3.40 & .498 & Good \\
\hline & Evaluation & 3.40 & .563 & Good \\
\hline & Creativity & 2.60 & .675 & Good \\
\hline \multirow{3}{*}{ Collaboration Skills } & Teamwork & 3.53 & .571 & Very Good \\
\hline & Networking & 3.53 & .681 & Very Good \\
\hline & Sharing & 3.30 & .794 & Good \\
\hline \multirow{3}{*}{ Awareness Skills } & Ethics & 3.40 & .563 & Good \\
\hline & Legal literacy & 3.47 & .571 & Good \\
\hline & Safeguarding self & 2.83 & .747 & Good \\
\hline \multicolumn{2}{|c|}{ Average } & 3.28 & .232 & Good \\
\hline
\end{tabular}

TABLE VIII: STUDENT'S AVERAGE SCORE OF DIGITAL LITERACY SKILLS BEFORE AND AFTER STUDY THROUGH LEARNING MODEL

\begin{tabular}{|c|c|c|c|c|c|c|c|c|}
\hline \multicolumn{9}{|c|}{$N=30$} \\
\hline \multirow{2}{*}{ Digital Literacy Skills } & \multirow{2}{*}{ Index } & \multirow{2}{*}{ Items } & \multicolumn{2}{|c|}{ Pre-Test } & \multicolumn{2}{|c|}{ Post-Test } & \multirow{2}{*}{$t$} & \multirow{2}{*}{$p^{*}$} \\
\hline & & & $\overline{\mathrm{X}}_{1}$ & $\mathrm{SD} \cdot 1$ & $\overline{\mathrm{X}}_{2}$ & $\mathrm{SD} \cdot 2$ & & \\
\hline \multirow{3}{*}{ Operation Skills } & Cognition & 6 & 3.31 & .472 & 3.63 & .463 & -7.089 & .000 \\
\hline & Innovation & 4 & 2.41 & .864 & 2.87 & .806 & -7.635 & .000 \\
\hline & Presentation & 4 & 2.93 & .736 & 3.25 & .658 & -5.302 & .002 \\
\hline \multirow{3}{*}{ Thinking Skills } & Analysis & 3 & 3.11 & .505 & 3.33 & .495 & -3.440 & .005 \\
\hline & Evaluation & 4 & 3.08 & .492 & 3.40 & .422 & -5.517 & .000 \\
\hline & Creativity & 3 & 3.36 & .582 & 3.65 & .680 & -4.557 & .000 \\
\hline \multirow{3}{*}{ Collaboration Skills } & Teamwork & 3 & 3.34 & .483 & 3.61 & .463 & -4.558 & .000 \\
\hline & Networking & 3 & 3.26 & .633 & 3.62 & .741 & -4.646 & .000 \\
\hline & Sharing & 4 & 3.00 & .412 & 3.21 & .472 & -5.767 & .000 \\
\hline \multirow{3}{*}{ Awareness Skills } & Ethics & 9 & 3.46 & .583 & 3.88 & .786 & -6.786 & .000 \\
\hline & Legal literacy & 7 & 3.36 & .653 & 3.84 & .810 & -7.709 & .000 \\
\hline & Safeguarding self & 4 & 3.57 & .521 & 3.97 & .786 & -5.845 & .000 \\
\hline \multicolumn{2}{|c|}{ Average score } & 54 & 38.24 & 4.644 & 42.32 & 4.692 & -10.887 & .000 \\
\hline
\end{tabular}

\section{CONCLUSION}

To full fill the need, facilitation and progress in the learning process of the students. The most appropriate method of blended learning is to add a variety of communication channels to enable students to reflect on and improve learning outcomes. Teachers should be open-minded about using modern technology in teaching and design teaching materials. Including the availability of instructors and knowledge about managing online learning and communication. And also the ability to attract students, the answer questions, providing advice and reflections on learning to students and so on.

In online learning need to educate the students to use e-learning experience possible, along with demonstration tools and systems used in ways that are constructive. Because the use of e-learning technologies in learning are some complicated technology that requires skills and good teaching. Students should be introduced gradually in order to capitalize on the learning of the students themselves. In addition, teachers should be prepared media and electronic learning resources are diverse and modern. Including the preparation of materials for teaching in a traditional classroom is ready to provide continuity in the event of instruction.

\section{CONFLICT OF INTEREST}

The authors declare no conflict of interest.

\section{AUTHOR CONTRIBUTIONS}

There are no co-authors for this paper, so there are no 
co-authors' contributions.

\section{REFERENCES}

[1] V. Panich, Approach of Learning for Students in the $21^{\text {st }}$ Century, Bangkok: Foundation of Sodsri- Slidwong, 2012, ch. 1, pp. 19-20.

[2] J. M. Dirkx, J. Mezirow, and P. Cranton, "Musing and reflections on the meaning context and process of transformative learning: A dialogue between John M. Dirkx and jack Mezirow," Journal of Transformative Education, vol. 4, no. 2, pp. 123-139, 2006.

[3] P. Cranton and E. Carusetta, "Developing authenticity as a transformative process," Journal of Transformative Education, vol. 2, no. 4, pp. 276-293, 2004.

[4] UNESCO, "Learning: The treasure within report to UNESCO of the International commission on education for twenty-first century," Vendôme France: Presses Universitaires de, pp. 16-20, 1996.

[5] C. R. Graham, "Blended learning systems: definition, current trends, and future directions," Handbook of Blended Learning: Global Perspectives, San Francisco, CA: Pfeiffer, 2005, pp. 11-13.

[6] J. E Rooney, "Blending learning opportunities to enhance educational programming and meetings," Association Management, vol. 55, no. 5, pp. 26-32, 2003.

[7] A. Hofmann, "Developments in blended learning," Economics and Organization of Enterprise, vol. 1, no. 1, pp. 55-62, 2008.

[8] M. Kerres and C. Witt, "A didactical framework for the design of blended learning arrangements," Journal of Educational Media, vol. 28 no. 2-3, pp.101-113, 2003.

[9] J. P. McCarthy and L. Anderson, "Active learning techniques versus traditional teaching styles: two experiments from history and political science," Innovative Higher Education, vol. 24, no. 4, pp. 279-294, 2000.

[10] J. Namon, "Development of AAA Model for blended learning based on the philosophy of sufficiency economy," Major: King Mongkut's University of Technology North Bangkok, 2007.

[11] N. Chaiyama, "Development of standardized test of higher order thinking skills for the undergraduate students," International
Proceeding $4^{\text {th }}$ Institute of Physical Education International Conference, 2014, pp. 75-79.

[12] L. W. Anderson and D. R. Krathwohl, "A taxonomy for Learning, teaching, and assessing: A revision of Bloom's taxonomy of educational objectives," New York: Addison Wesley Longman, 2001.

[13] K. Sriphan, "Development of standardized test of information literacy skills for Chiang Mai university students," Master of Art, thesis in information studies, Chiang Mai University, 2010.

[14] W. Techataweewan and U. Pasertsin, Development of Digital Literacy Test for Undergraduate Students, Bangkok, Department of Library and Information Science, Faculty of humanities, Srinakariwirot University, 2016.

[15] F. Mossavar-Rahmani and C. Larson-Daugherty, "Supporting the hybrid learning model: A new proposition," MERLOT. Journal of Online Learning and Teaching, vol. 3, no. 1, pp. 67-78, 2007.

[16] L. Jeffrey, B. Hegarty, O. Kelly, M. Penman, D. Coburn, and J. McDonald, "Developing digital information literacy in higher education: Obstacles and supports," Journal of Information Technology Education, vol. 10, pp. 383-413, January 2011.

Copyright $\odot 2019$ by the authors. This is an open access article distributed under the Creative Commons Attribution License which permits unrestricted use, distribution, and reproduction in any medium, provided the original work is properly cited (CC BY 4.0).

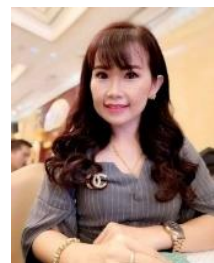

Nuanphan Chaiyama is an assistant professor in the Faculty of Education, Thailand National Sports University Udon Thani Campus, Thailand. She received her $\mathrm{Ph}$. D. degree from Khon Kaen University Thailand in 2011. The major field of study is educational technology. Her academic background is computer education emphasis in teaching computer and technology. Her research interests are teaching and learning style, multimedia integration, and instructional strategy which include the development and improvement of various multimedia production systems in both face-to-face and online learning environments. 